\title{
Dislocation of Intravenous Port Systems - Three Case Reports
}

\author{
Katharina Seck Steffen Saupe Marion Kiechle Nadia Harbeck \\ Frauenklinik und Poliklinik der Technischen Universität München, Germany
}

\section{Key Words}

Venous port system - Intravenous chemotherapy . Catheter fracture

\section{Summary}

Background: Many patients with intravenous chemotherapy have an intravenous port system because of high tissue toxicity of most chemotherapeutic agents in the case of paravasation. With more port systems implanted, the rate of complications is increasing. Apart from catheter thrombosis, we primarily know of fracture of the port catheter. Case Report: We describe 3 patients of our chemotherapeutic clinic who experienced complications of the intravenous port system implanted in the vena brachialis. All of them showed fracture and loss of the port catheter, followed in some cases by symptoms such as cardiac problems. Conclusion: We have to discuss the use of intravenous port systems. Besides their comfortable use, intravenous port systems have to be handled with care and it has to be considered in every case if there really is the need for an implantation.

\section{Introduction}

Increasing incidence of several malignancies is correlated with an increasing number of chemotherapies being applied. Apart from some orally administered chemotherapeutic agents, most patients need an intravenously applied chemotherapy. As an immediate consequence, more intravenous port systems are used because of the following reasons.

Some chemotherapeutic agents like anthracyclines, which are very frequently used in adjuvant as well as palliative

\author{
Schlüsselwörter \\ Intravenöses Portsystem · Intravenöse Chemotherapie · \\ Katheterkomplikationen
}

\section{Zusammenfassung}

Hintergrund: Viele Patienten mit intravenöser Chemotherapie besitzen ein intravenös liegendes Portsystem aufgrund der hohen Gewebetoxizität der meisten Chemotherapeutika im Fall eines Paravasates. Je mehr Portsysteme implantiert werden, desto höher ist die Rate der Komplikationen; neben der Portvenenthrombose treten hauptsächlich Katheterkomplikationen auf. Fallbericht: Wir berichten von 3 Patientinnen aus unserer Chemoambulanz, die Komplikationen des Portsystems im Bereich der Vena brachialis zeigten, nämlich Katheterdislokationen, was sogar in einem Fall zu kardialen Symptomen geführt hat. Zusammenfassung: Man muss die Verwendung der intravenösen Portsysteme diskutieren. Insbesondere aufgrund des angenehmen Gebrauchs eines Ports muss dieser sorgfältig benutzt werden und in jedem Fall muss die Indikation zur Implantation neu gestellt werden. therapy of breast cancer, may cause substantial tissue toxicities when there is a paravasate [1]. In addition, most elderly patients present with poor venous conditions which will eventually get worse if several chemotherapies are applied via peripheral venous catheters. Thus, in routine oncological care, the use of intravenous port systems has become very common.

Intravenous port systems can be implanted in different locations: either in the infraclavicular region via the subclavian vein or in the forearm via the vena brachialis [2]. The injec-

\section{KARGER}

Fax +497614520714

Information@Karger.de

www.karger.com (c) 2009 S. Karger GmbH, Freiburg

Accessible online at:

www.karger.com/brc 

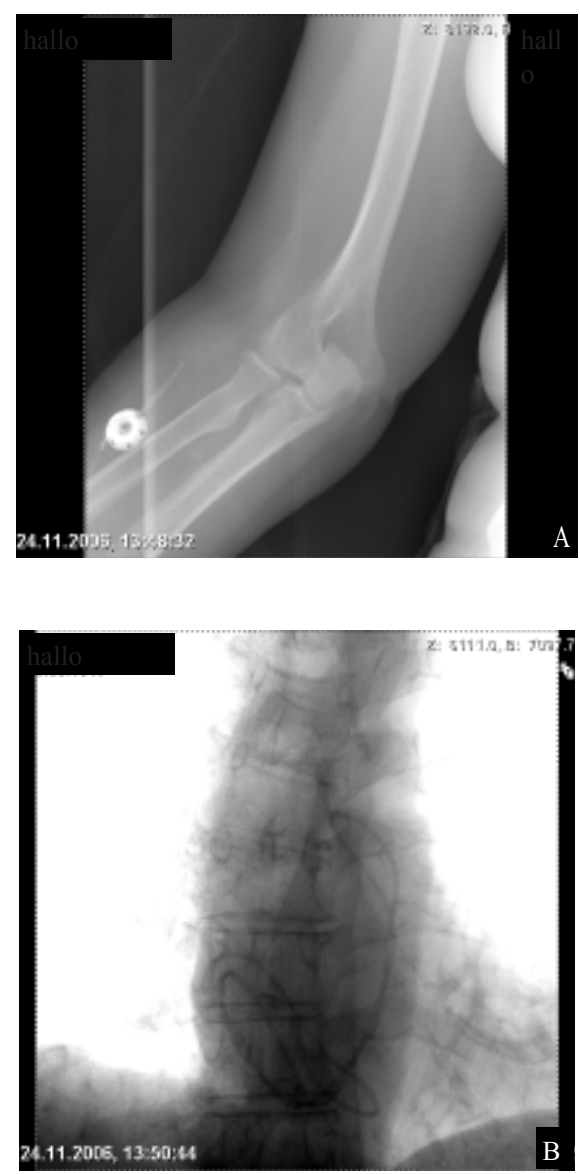

Fig. 1. A Fracture of the catheter cranial of the injection port reservoir.

B The port catheter dislocated through the right heart into the truncus pulmonalis.
Fig. 2. The port catheter dislocated into the vena cava superior and with a loop through the right heart into the truncus pulmonalis.

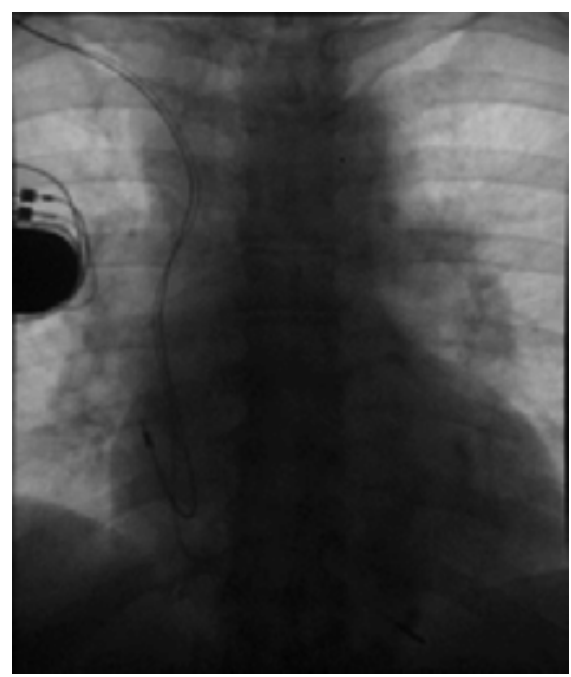

port which was used for chemotherapy. During a routine bisphosphonate application, the infusion suddenly stopped. Upon X-ray control, dislocation of the intravenous port system was seen. The catheter was detached from the port reservoir and dislocated into the right atrium and ventricle until the truncus pulmonalis. The apparent reason was an accidental rupture of the catheter about $5 \mathrm{~cm}$ beyond the port injection system (fig. 1). There was an immediate risk of perforation so the whole port system was removed instantly. For the whole time, the patient did not have any symptoms attributable to the port catheter dislocation.

The second patient was an 84-year-old woman who had an exulcerated breast carcinoma with metastases in lung, bones, and lymph nodes. Because of this diagnosis, the patient got a port system in the vena brachialis. The state of health of this patient was so poor that she received a low-dose weekly chemotherapy regimen (paclitaxel $80 \mathrm{mg} / \mathrm{m}^{2}$ q7) which she tolerated well. During therapy, the loco-regional relapse became smaller and clinical symptoms improved. At cycle 15, the patient complained of weakness and dizziness together with dyspnea, which she had never reported before. Because of these symptoms, a port needle was inserted into the port injection system to draw blood for some laboratory tests; after insertion, it was noted for the first time that it was not possible either to flush the system with saline solution or to aspirate blood. Thus, it was necessary to perform an X-ray of the port system: It showed the dislocation of the catheter which was lying with both ends in the vena cava superior and with a loop through the right heart into the truncus pulmonalis (fig. 2). Because of the clinically unstable situation of the patient, the whole port system was removed in an emergency session. After this operation, the symptoms, such as heart failure and weakness, lasted for about 2 weeks.

The third patient had a FIGO IIIC ovarian carcinoma. After tumorreductive surgery with a residual tumor of less than $1 \mathrm{~cm}$, she needed a platinum-based chemotherapy (carboplatin AUC 5/ paclitaxel $175 \mathrm{mg} / \mathrm{m}^{2}$ q21). Before starting the chemotherapy, the intravenous port system was implanted into the vena subclavia. At cycle number 5, the patient got up from her hospital bed while the infusion (total time requirement $6 \mathrm{~h}$ ) was still running; after this incident, the infusion stopped spontaneously and it was not possible to start it again. We first thought of a mere needle dislocation, so we removed the needle and reinserted a new one; however, it was still not possible to flush the port or aspirate blood. The subsequent X-ray of the whole port system showed a dislocation of the connector between the port injection system and the catheter (fig. 3). Consequently, the port system could not be used and was explanted the next day. Then, the last cycle of chemotherapy was applied via a peripheral venous catheter without any complications. 

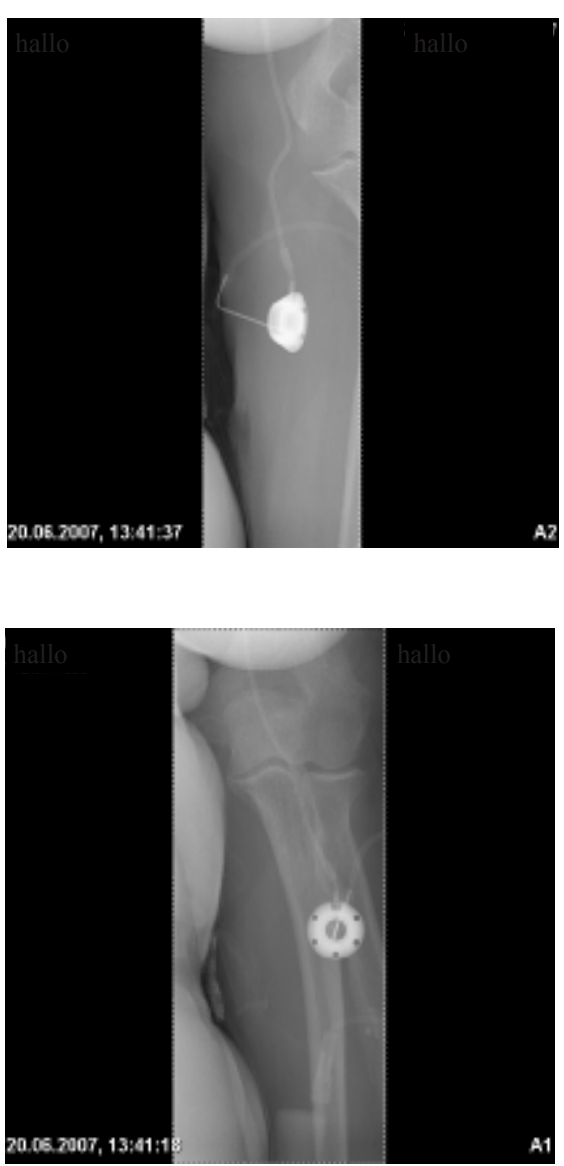

Fig. 3. Dislocation of the connector between port injection system and catheter.
Therefore, we have to look for alternatives or any possibilities to avoid complications of intravenous port systems. On the one hand, there is the possibility of using less intravenous port systems and more peripheral venous catheters; here, the risk of paravasation should be considered. One has to distinguish between chemotherapeutical substances with high and those with low tissue toxicity potential. The decision for or against a venous port system should be made accordingly.

Furthermore, one has to discuss the optimal time for explantation of the port systems, in particular in the adjuvant setting: for example, the first patient only received a bisphosphonate therapy after completion of adjuvant anthracyclinecontaining chemotherapy; in the case of a bisphosphonate therapy or an antibody treatment, port systems should only be maintained if the peripheral venous situation is poor. A statistically high risk of a relapse or mere temporary convenience should not be the only reason for keeping the port system in place.

In addition, the venous port system has to be handled with care. Before every application, the system needs to be flushed with saline; in order to keep the port system clean, a heparin lock needs to be performed after each treatment and at least once every 8-12 weeks [4]. Needles should be inserted perpendicular to the implanted port after locating the port container in order to avoid incomplete needle insertion and air influx.

In conclusion, intravenous port systems need to be handled with care, and indications for using these systems should consider potential complications. With every patient, implantation of such a system needs to be decided individually after the discussion of advantages and disadvantages of the port system. Problems occurring during routine use of intravenous port systems should be evaluated immediately as our cases demonstrate. Even without the patient initially experiencing clinical symptoms, severe complications may have occurred which only become apparent by sudden problems of flushing the port or aspirating blood. Nevertheless, knowing the appropriate and correct use and not forgetting potential complications, an intravenous port system is a comfortable and safe device.

\section{Acknowledgement}

The authors thank Dr. Stollfuß from the Abt. Röntgendiagnostik, TU Munich, for providing the X-ray images.

\section{Conflict of Interest}

The authors declare that they have no conflicts of interest. 


\section{References}

1 Bach F, Videbaek C, Holst-Christensen J, Boesby S: Cytostatic extravasation: a serious complication of long-term venous access. Cancer 1991;68:538 539.

2 Peynircioglu B, Arslan EB, Cil BE, Geyik S, Hazirolan T, Konan A, Balkanci F: Subcutaneous venous port implantation in patients with bilateral breast surgery. Cardiovasc Intervent Radiol 2007;30:405-409.

3 Cook $^{\circledast}$ Vascular Incorporated: Product Information. Suggested Instructions for use of Vital Port Vascular Access Systems. www.cookmedical.com/ di/content/mmedia/FM-1270-L.pdf.

$>4$ Vescia S, Baumgärtner AK, Jacobs VR, KiechleBahat M, Rody A, Loibl S, Harbeck N: Management of venous port systems in oncology: a review of current evidence. Ann Oncol 2008;19:9-15.

5 Beherend M, Paboura E, Raab R: Late embolization of an unfractured port catheter into the heart report of a case. Surg Today 2002;32:724-726.
6 Franey T, DeMarco LC, Geiss AC, Ward RJ: Catheter fracture and embolization in a totally implanted venous access catheter. JPEN J Parenter Enteral Nutr 1988;12:528-530.

7 Gowda MR, Gowda RM, Khan IA, Punukollu G, Chand SP, Bixon R, Reede DL: Positional ventricular tachycardia from a fractured mediport catheter with right ventricular migration - a case report. Angiology 2004;55:557-560.

8 Nace CS, Ingle RJ: Central venous catheter pinchoff and fracture: a review of two under-recognized complications. Oncol Nurs Forum 1993;20:12271236.

9 Prager D, Hertzberg RW: Spontaneous intravenous catheter fracture and embolization from an implanted venous access port and analysis by scanning electron microscopy. Cancer 1987;60:270-273.

10 Rubenstein RB, Alberty RE, Michels LG, Pederson RW, Rosenthal D: Hickman catheter separation. JPEN J Parenter Enteral Nutr 1985;9:754-9757.
11 Stokes K, Staffenson D, Lessar L, Sahni A: A possible new complication of subclavian stick: conductor fracture. Pacing Clin Electrophysiol 1988;10:748.

12 Stokes K, McVenes R: Pacing lead fracture, a previously unknown complication of subclavian stick. Pacing Clin Electrophysiol 1988;11:855.

13 Debourdeau P, Zammit C, Pavic M, Bensaid B Farge-Bancel D: Venous thromboembolism associated with long-term use of central venous catheters in cancer patients. Rev Med Interne 2007;28:471483.

14 Magney JE, Flynn DM, Parsons JA, Staplin DH Chin-Purcell MV, Milstein S, Hunter DW: Anatomical mechanisms explaining damage to pacemaker leads, defibrillator leads, and failure of central venous catheters adjacent to the sternoclavicular joint. Pacing Clin Electrophysiol 1993;16:445457. 